\title{
Socio-environmental integration of hydropower facilities
}

\author{
Atle HARBY ${ }^{1}$, Torbjørn FORSETH², Tor Haakon BAKKEN ${ }^{1,3}$, Audun RUUD ${ }^{2}$

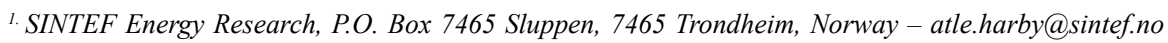 \\ 2.Norwegian Institute for Nature Research, P.O. Box 5685 Sluppen, 7485 Trondheim, Norway - torbjorn.forseth@nina.no,audun.ruud@nina.no \\ 3. Norwegian University for Science and Technology, 7491 Trondheim, Norway - tor.haakon.nakken@sintef.no
}

\begin{abstract}
Centre for Environmental Design of Renewable Energy (CEDREN) is a research centre focusing on hydropower production and environmental impacts of hydropower. The main objective of CEDREN is to develop and communicate design solutions for renewable energy production that address environmental and societal challenges at local, regional, national and global levels. Environmental design means that planning, building and operation have to include technical, economic, environmental and socio-political aspects throughout the whole life-span of the project. Methods and tools to ensure environmental design are developed in CEDREN and applied to case studies in Norway and internationally. These methods and tools focus on finding physical and biological bottlenecks for affected species and ecosystems by mapping, modelling and analysis of both physical conditions and ecological status. CEDREN proposes different measures, tools and methods to improve the environmental conditions as well as how to maintain or increase the power production. In addition, a strong focus must be made on political governance to ensure more representative participation of relevant stakeholders in the process of finding the best technical, economic and political solutions for power production, the environment and the society.

Key research findings used to develop relationships between physical factors like flow, flow fluctuations, water temperature, water velocity, water depth and water-covered area and biological response will be shown. Examples of improved methods for better planning procedures with stakeholder engagement will be proposed. Examples of methods and tools for environmental design of hydropower will be given for several regulated rivers in Norway and abroad.
\end{abstract}

Key-words: social impacts, environmental impacts, hydropower, environmental design.

\section{Intégration socio-environnementale des installations hydroélectriques}

RÉSUMÉ. - Le Centre pour le design environnemental des energies renouvelables (CEDREN) est un centre de recherche dédié aux thèmes de la production d' énergie hydraulique et de ses impacts sur l'environnement. L'objectif principal du CEDREN est de développer et de communiquer des solutions pour la production d'énergie renouvelable qui prennent en compte les défis environnementaux et sociétaux au niveau local, régional, national et mondial. « Design environnemental» signifie que la planification, la construction et l'exploitation doivent inclure les aspects techniques, économiques, environnementaux et socio-politiques pendant toute la durée de vie du projet. Les méthodes et les outils visant à assurer le « design environnemental » sont développés au CEDREN et ensuite appliqués dans le cadre d'études de cas en Norvège et à l'étranger. Ces méthodes et ces outils se concentrent sur l'identification de conditions physiques et biologiques et de leur influence, et comprennent la cartographie, la modélisation et l'analyse des conditions physiques et écologiques. Le CEDREN propose différentes mesures, outils et méthodes pour améliorer les conditions environnementales et pour maintenir ou augmenter la production d'énergie. De plus, une attention particulière est accordée à la gouvernance politique afin d'assurer davantage de participation représentative de la part des différents intervenants pour trouver les meilleures solutions techniques, économiques et politiques quant à la production d'énergie, l'environnement et la société.

Nous présenterons nos principaux résultats qui sont utilisés pour identifier les liens entre les facteurs physiques tels que le débit, les fluctuations de débit, la température de l'eau, la vitesse du courant, la profondeur d'eau et de la surface mouillée, et les processus biologiques. Nous proposerons des exemples d'améliorations quant aux méthodes utilisées dans les procédures de planification afin d'améliorer la participation des intervenants. Enfin, nous présenterons des exemples de méthodes et d'outils pour le design environnemental de la production d'hydroélectricité pour plusieurs fleuves régulés en Norvège et à l'étranger.

Mots-clés : les impacts sociaux, les impacts environnementaux, l'énergie hydroelectrique, design de l'environnement.

\section{INTRODUCTION}

Hydropower is the world's largest renewable energy source, and further development is expected. Hydropower plants have also been installed world-wide many decades ago, and these plants need refurbishment and upgrading. Hydrological as well as market and grid situations are changing, leading to a need for re-design of many hydropower facilities. Further, modern requirements to include environmental and social aspects of hydropower re-design, re-licensing and expansions will lead to new solutions. In addition, future energy scenarios include large amounts of non-regulated renewables, especially wind and solar power. In such systems, there will be an increasing need for hydropower which has excellent capabilities for fast regulation, balancing and large-scale storage, with changing demand 
and changing wind and solar conditions. At the same time the environmental consequences need to be carefully evaluated and addressed. The research within CEDREN is focusing on many of these aspects and the result and knowledge developed within CEDREN will hopefully lead to improved decision-making and more sustainable hydropower solutions

\section{RE-LICENSING, RE-DESIGN AND NEW SOLUTIONS}

The Norwegian hydropower system includes many old hydropower plants that are due for re-licensing and refurbishment, also giving the possibility of applying new solutions to meet future needs for hydropower operation and other services.

Through experiments and case studies, CEDREN is focusing on how mitigation and adaptations in river regulation can improve the environmental conditions [Forseth and Harby 2014]. A combination of targeted environmental flow regimes and physical mitigation is often the best way to mitigate adverse effects in regulated rivers. Substrate conditions and the water-covered area at critical periods of the year are often the major bottlenecks for many species in the aquatic ecosystem, and if possible, mitigation should focus on these elements. More knowledge is needed to fully understand the flow and substrate-habitat requirements for different species, especially when modern river regulation schemes, climate change impacts and new requirements for ecosystem services are considered. We should also focus on the physical conditions leading to bottlenecks in the ecosystem rather than focusing on improving conditions that are not crucial for survival. Figure 1 illustrates the process of how this is applied for evaluating and improving both power production and environmental impacts in regulated rivers.

In the River Kvina in southern Norway, the methodology in the handbook [Forseth and Harby 2014] has been applied in an attempt to develop win-win solutions for salmon and hydropower production. The River Kvina is a heavily regulated river where $70 \%$ of the natural inflow is stored in several reservoirs and transferred to a neighbouring catchment from Homstølvatn to feed the Tonstad Hydropower Plant. This transfer cause large reductions in discharge to the salmon producing parts of the river downstream Homstølvatn, and estimates indicate that the production capacity for salmon smolts was reduced by more than $50 \%$ after regulation (annual loss of 20000 smolts). To increase hydropower production, the power company suggested transferring more water (increasing the total transfer to $74 \%$ ) and building a new run-of-the-river power station at the present day migration barrier for salmon (Rafoss waterfall). At the same time, to increase salmon production, the company initiated an environmental design project, offering to expand the salmon producing stretch from 13 to $19 \mathrm{~km}$ by facilitating two-way migration solutions at the present barrier, establishing a water bank for environmental flow releases and restoring deteriorated (in part due to regulation) habitat.

Analysis of hydrological alteration combined with existing population data identified low flow periods during winter (reducing salmon winter survival and causing egg stranding) and mid-summer (causing high density dependent mortality) as major hydrological bottlenecks for salmon smolt production. In addition, water flow during smolt migration was low and stable in dry years, potentially influencing smolt survival. Similarly, according to local anglers, low and stable flow conditions during dry summers provided poor fishing conditions. Flow duration curves indicated that increasing the present minimum flows $\left(1.3 \mathrm{~m}^{3} / \mathrm{s}\right.$ during winter and $3.7 \mathrm{~m}^{3} / \mathrm{s}$ during summer) could be done with relatively small volumes of water, particularly during winter. Because low and stable flow during smolt migration and mid-summer represented rare events, artificial freshets for better smolt migration and improved fishing conditions could also be provided without major costs to hydropower production. $20 \%$ of the planned additional water transfer was set as the maximum water bank (in total 20 million $\mathrm{m}^{3}$ of water per year) available for environmentally designed flows. Several flow scenarios were tested, and the final suggestion involved:

- Increasing minimum winter flow from 1.3 to $6 \mathrm{~m}^{3} / \mathrm{s}$.

- Increasing minimum summer flow from 3.7 to $5 \mathrm{~m}^{3} / \mathrm{s}$.

- Conditional (in case of low and stable flow conditions halfway through the smolt migration period) artificial smolt freshets obtained by increasing flow by $30 \%$ and maintaining that level for 48 hours.

- Conditional (in case of low and stable flow conditions during three 20 days periods in the fishing season) artificial fishing freshets obtained by enhancing natural flow increases as to reach minimum $15 \mathrm{~m}^{3} / \mathrm{s}$ for 48 hours during a maximum of three occasions each year.

On average this suggestion involves annual flow releases from the Homstølvatn reservoir at $16 \mathrm{Mm}^{3}$, corresponding to $80 \%$ of the water bank and $16 \%$ of the total additional water available in the reservoir after the suggested transfer. Some years the releases will be smaller, in others lager. Based on the rules of thumbs presented in the handbook, these measures to reduce the effects of hydrological bottlenecks will increase smolt production in the existing and new salmon producing area (see below) by 7400 to 9900 smolts (minimum and modal estimates).

Mapping of shelter availability and spawning areas according to the procedures in the handbook identified some river segments with abundant spawning opportunities but with few shelters and one river stretch almost without spawning areas but with abundant shelters. Suggested habitat mitigation measures (construction of cell weirs to increase shelter availability and installation of spawning gravel in selected sites) were estimated to increase smolt production by 1300 to 1800 smolts.

A major part of the estimated gains in smolt production in the environmental design project comes from expanding the river stretch available for the salmon population (additional $6 \mathrm{~km}$ ). Two-way migration solutions to access this additional stretch have been developed as part of a separate project, not presented here. Mapping of shelter availability and spawning areas was used to categorise river segments into low, moderate and high productivity, using standard smolt densities according to rule of thumbs in the handbook. After accounting for remaining losses due to hydrological bottlenecks with the suggested minimum discharges $\left(6 \mathrm{~m}^{3} / \mathrm{s}\right.$ and $5 \mathrm{~m}^{3} / \mathrm{s}$ during winter and summer, respectively) we estimated that this river stretch would produce between 16000 and 22000 smolts.

According to our estimates the annual losses of salmon production after the existing regulation $(20000$ smolts $)$ can likely be fully compensated. At the same time, increased hydropower production in the existing Tonstad Power Plant and the planned Rafoss Power Plant may provide between 100 and $140 \mathrm{MWh}$ of new renewable energy. This exemplifies the potential for win-win solutions by using the environmental design concept described in the handbook, particularly in cases involving expansions of both the hydropower and salmon systems. In other cases, increases in salmon production may be obtained at no or minimum costs for hydropower production (smarter use of available water). 


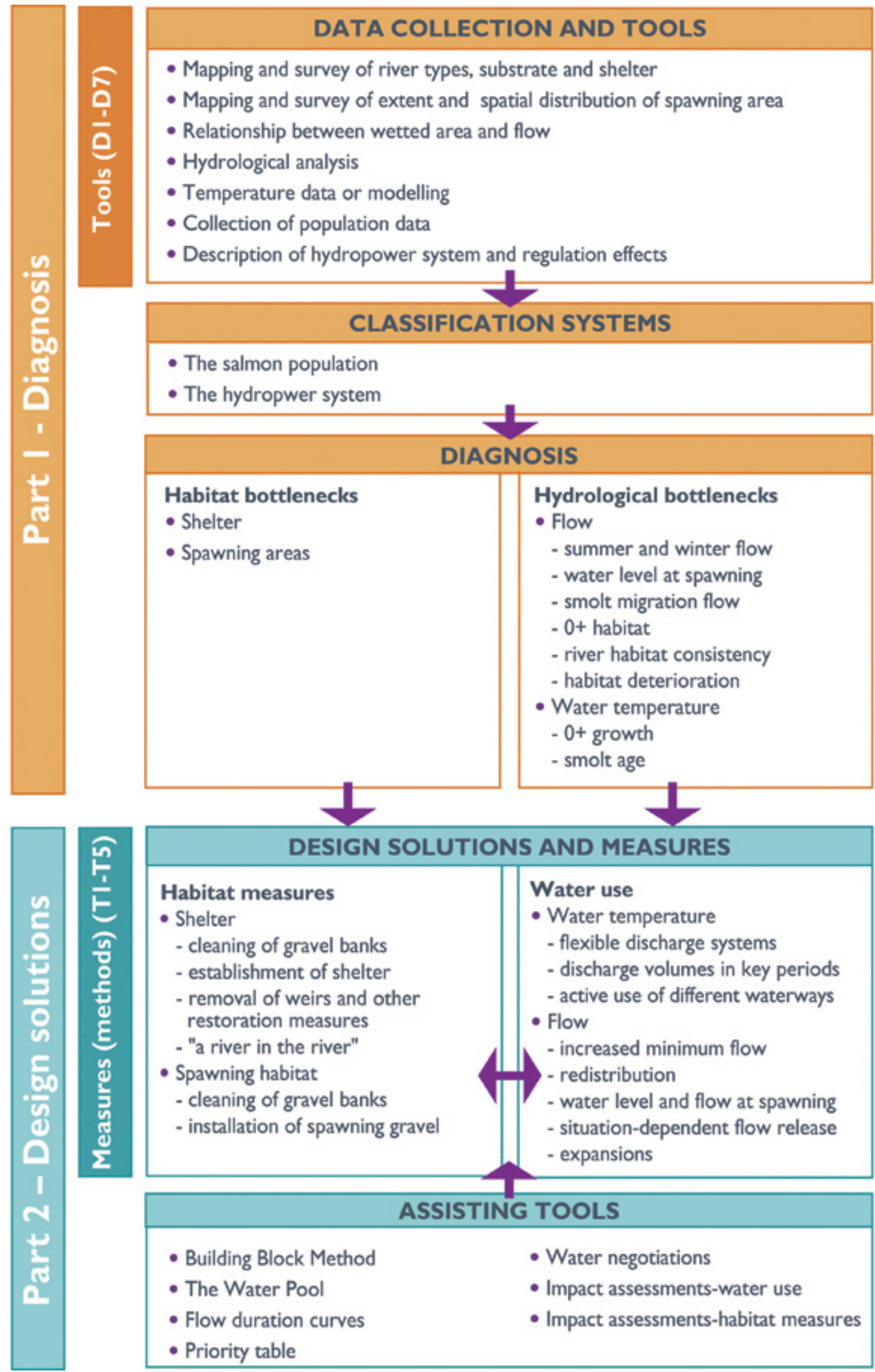

Figure 1 (from Forseth and Harby 2014) : A description of the overall structure of the environmental design concept, which is designed to help the reader better understand the processes behind effective measures taken in regulated river systems. The handbook is organised into two main parts. Part 1 describes how to arrive at a diagnosis, while part 2 describes how effective design solutions can be developed and implemented. 


\section{HYDROPEAKING AND LARGE-SCALE ENERGY BALANCING}

Existing Norwegian hydropower reservoirs have considerable storage capacity that can be exploited for balancing services within the current regulations regarding highest and lowest regulated water levels. The balance power capacity of Norwegian hydroelectric power stations can be increased by installing larger turbines and generators in some power stations, and by installing (reversible) pump turbines to pump water between two reservoirs.

Implications for the operational schemes of the affected reservoirs when balancing wind power from the North Sea area are analysed. Based on time series of stage and live storage volume of the upper and lower reservoirs, balancing power on daily basis was simulated on top of the current operation of three existing power plants. The objectives were to compare the current patterns of water level fluctuations to the simulated patterns (season, frequency, rate of change) and to analyse which factors determine how much power can actually be balanced compared to how much is required to be balanced (turbine capacity, free reservoir volumes). This analysis is based on the results from a preliminary case study on large-scale balancing services from Norwegian hydropower [Harby et al. 2013], showing the technical potential to develop 20,000 MW of new hydro where about 10,000 MW includes pumping. The main scenario involves twelve new power stations with a combined power output of 11,200 MW. It is envisaged that these power stations would be constructed with new tunnels to an upstream reservoir and to the downstream outflow into a reservoir or to the sea. The power generation outputs in the scenario were chosen mainly so that the water level change in the upper and lower reservoirs does not exceed $13 \mathrm{~cm} /$ hour. According to research into the stranding of salmon in rivers, the water level should not sink by more than $13 \mathrm{~cm} /$ hour [Harby and Halleraker 2001]. Although this is not directly applicable to lakes, this was used as a rule of thumb for acceptable water level reduction in reservoirs. Results of the study on alterations in physical conditions will be shown as well as the potential impact on the aquatic ecosystem.

Hydropeaking from power plants with outlet directly into rivers, will lead to rapid fluctuations in discharge and water level in the downstream river which may cause negative impacts to the riverine ecosystem. In controlled environments, we exposed fish to stress in the form of fluctuations in flow rates and water levels, and compared the fish to a control group of fish that were not exposed to these rapid changes. In the winter it was not evident that fish growth and energy balance were affected by hydropeaking, but in the summer we detected a certain effect. This indicates that we need to take seasonal factors into account when making recommendations for hydropower operations [Puffer 2014]. Previous studies have shown that stranded fish may survive several hours in a dewatered substrate [Harby and Halleraker 2001], but it is unknown how this affects future development.

We investigated the abundance and density of invertebrates in four rivers with different hydropeaking operations and two rivers with stable hydropower regulation. All rivers where sampled both upstream and downstream the power plant outlet in the fall. Upstream the outlet, the density of invertebrates was almost similar in the deep part (thalweg) of the river compared to the river edges (ramping zone) in all rivers. In the rivers with peaking, the density of invertebrates was much higher in the thalweg of the river. This effect was not seen in the two regulated rivers without peaking. The diversity in the ramping zone was also much smaller than in the thalweg or in the rivers with stable regulation.

\section{GOVERNANCE IN HYDROPOWER DEVELOPMENT IN NORWAY}

In sum, main political and regulatory drivers and barriers impacting upon the current and future hydropower development in Norway are quite complex and fragmentary, and there is currently no overall target providing a general direction for hydropower development. Given the lack of an overall, coherent approach, the interaction between the different levels of governance does not demonstrate a specific, coherent pattern. At the same time the interest for further expansion of hydropower production is growing. Knowledge and documentation stand out as crucial in two major ways: (1) A need to reinforce the accessibility and transparency of the licensing process; and (2) complementary and updated research and documentation on how to meet the challenges raised by the renewed interest in, and further demand for, hydropower.

An increasingly important factor affecting hydropower in Norway is the role of both EU energy and water policy. The full effect of the EU's energy policy on Norwegian hydropower development is, however, still pending, due to the uncertainty of how Norway will implement the EU Water Framwork Directive and the targets for the follow-up of the EU RES Directive in practice.

As a way of dealing with these new challenges, steps could be taken to establish a data bank of knowledge gained aiming at some kind of standardisation of insights and data gained from the assessment of the various projects. Such an informational resource could also contribute to a higher degree of transparency and legitimacy of the licensing processes. It is important to point out, however, that increasing the status and quality of case-based knowledge will not automatically influence either the outputs of the licensing processes, or the difficult issue of resolving trade-offs between environmental, economic and social concerns. Given the predominantly case-by-case approach to hydropower development, a more coherent knowledge basis will not necessarily change the priority between different interests and concerns in a general manner. As long as the volume of discharge water and the water level itself has to be considered within the specific context of each case, it is difficult to say whether a more standardised knowledge basis could be employed, and eventually systematically impact on the outcome of the trade-offs. At the same time, the possibility of drawing on knowledge and experiences from comparable cases, and reviewing the underlying knowledge and documentation by third parties, could constitute an important step towards a strengthening of the overall legitimacy of the licensing system.

\section{REFERENCES}

Forseth T And Harby A (Eds.) (2014) - Handbook for Environmental Design in Regulated Salmon Rivers. Nina Special Report Trondheim, Norway $\mathbf{5 3}$

Harby A. And Halleraker J.H. (2001) - Ecological Impacts of Hydro Peaking in Rivers. Journal Of Hydropower And Dams 4

Puffer M. (2014) — Effects Of Rapidly Fluctuating Water Levels On Juvenile Atlantic Salmon. doctoral theses at NTNU. $111 \mathrm{p}$.

Harby A., Sauterleute J., KorpÅs M., Killingtveit Å., Solvang E. And Nielsen T., Pumped Storage Hydropower (2013) Transition to Renewable Energy Systems. Wiley-VCH; Stolten, D. and Sherer, V. (eds). 597-618 